(2) Open Access Full Text Article

REVIEW

\title{
Amniotic membrane allografts: development and clinical utility in ophthalmology
}

\author{
This article was published in the following Dove Press journal: \\ Chronic Wound Care Management and Research \\ 9 December 2014 \\ Number of times this article has been viewed
}

\author{
Allison Rizzuti ${ }^{1,2}$ \\ Adam Goldenberg' \\ Douglas R Lazzaro'1,2 \\ 'SUNY Downstate Medical Center, \\ ${ }^{2}$ Kings County Hospital Center, \\ Brooklyn, NY, USA
}

\begin{abstract}
Amniotic membrane, the innermost layer of the placenta, is a tissue that promotes epithelialization, while decreasing inflammation, neovascularization, and scarring. It is used in the surgical management of a wide variety of ophthalmic conditions where it functions as a graft or patch in ocular surface reconstruction. The development of new preservation techniques, as well as a sutureless amniotic membrane, has allowed for easier, in-office placement, without the disadvantages of an operating room procedure. The purpose of this review is to describe the historical development of amniotic membrane in ophthalmology and to describe its current clinical applications, particularly focusing on recent advances.
\end{abstract}

Keywords: ocular surface, cornea, stem cells, prokera, allograft, patch, transplantation

\section{Introduction}

Amniotic membrane is the innermost layer of the placenta, which after proper cryopreservation techniques, is used to treat a wide variety of ophthalmic conditions. By serving as a basement membrane, amniotic membrane promotes epithelialization at the site of a tissue defect in order to effectively reconstruct the ocular surface. It has also been shown to decrease inflammation, neovascularization, and scarring, as well as to possess antimicrobial and analgesic effects. Its unique properties make the amniotic membrane a suitable substrate for the ex vivo growth of stem cells, and it is currently being used to facilitate stem cell transplants for patients with limbal stem cell deficiency. The development of the sutureless Prokera ${ }^{\circledR}$ (Bio-Tissue, Inc., Doral, FL, USA) and AmbioDisk ${ }^{\mathrm{TM}}$ (Katena/IOP, Costa Mesa, CA, USA) have allowed for an easier in-office application, eliminating the need for an operating room procedure. Herein, we review the development of the amniotic membrane and its clinical applications in ophthalmology, particularly focusing on recent advances.

\section{Historical perspective}

The use of amniotic membrane as a skin graft was first reported in 1910 by Dr JW Davis at the suggestion of WL Thorton, a third-year medical student at Johns Hopkins. ${ }^{1}$ While this initial trial was unsuccessful, Sabella ${ }^{2}$ and Stern $^{3}$ independently and successfully utilized amniotic membrane grafts as a treatment for burn patients. Preservation processes developed in the 1940s demonstrated that amniotic tissue could be processed and stored, thereby increasing its utility. Through time and experimentation, amniotic membrane grafts were found to be highly versatile, leading to their usage in a variety of fields including oral wound healing, ${ }^{4}$ otolaryngology, ${ }^{5}$ repair
Correspondence: Douglas R Lazzaro SUNY Downstate Medical Center 450 Clarkson Avenue

Brooklyn, NY I I 203, USA

$\mathrm{Tel}+\mathrm{I} 7182455460$

Email douglas.lazzaro@downstate.edu 
of myelomeningoceles, ${ }^{6}$ vaginal reconstructive surgery, ${ }^{7}$ neural repair in animal models, ${ }^{8}$ the prevention of surgical adhesions, ${ }^{9}$ closure of pericardium, ${ }^{10}$ and for ocular surface reconstruction.

The first report of amniotic membrane as a corneal graft was by De Rötth ${ }^{11}$ in 1940 as an attempt to find a tissue, which was similar to and more readily available than a corneal allograft. While this initial attempt was largely unsuccessful, British ophthalmologists Sorsby et $\mathrm{al}^{12}$ were successful in implementing amniotic membranes as corneal grafts resulting in the treatment of a total of 58 patients with caustic burns of the eye. Although the success of Sorsby et $\mathrm{al}^{12}$ with corneal amniotic membrane grafting was later replicated, the use of amniotic membranes as a corneal graft went relatively unreported for the next 30 years for no apparent reason, other than Collin's mention that "working with fetal membranes, however, is extremely difficult". ${ }^{13}$

Although unreported, preserved amniotic membrane was secretly and successfully used as a treatment for corneal damage in Soviet Russia. ${ }^{14}$ The analysis and subsequent discovery of the identity of this tissue as amniotic membrane by Batlle and Perdomo sparked Schaffer Tseng et $\mathrm{al}^{15}$ to reintroduce and expand this tissue's role in ocular reconstruction through the development of new methods of preservation, and to develop new surgical techniques.

\section{Mechanism of action and procurement}

The exact mechanism by which amniotic membrane serves to reconstruct a damaged ocular surface remains unclear, but it is thought that its high concentrations of cytokines and growth factors act to promote epithelial growth, while suppressing inflammation and scarring. ${ }^{14}$ Amniotic membrane acts as a basement membrane, which facilitates the migration of epithelial cells, reinforces adhesion, promotes differentiation, and prevents cellular apoptosis. The properties of amniotic membrane and the associated factors are extensive and beyond the scope of this review, but are briefly outlined in Table 1.

Amniotic membrane is obtained from consenting donors who are screened in the prenatal unit, excluding mothers with a drug or alcohol history and those with communicable diseases such as human immunodeficiency virus and hepatitis. The placenta is collected after elective cesarian section delivery and the amnion is isolated under sterile conditions, as described by Lee and Tseng. ${ }^{16}$ Although it has been suggested that fresh amniotic membrane is superior in terms of its antiinflammatory properties, the membrane is cryopreserved in order to prevent the transmission of blood-borne illnesses. ${ }^{17}$ It is stored in $50 \%$ glycerol and spread epithelial side up on nitrocellulose paper. The tissue is then frozen to $-80^{\circ} \mathrm{C}$ and may be stored for 2 years' post-delivery.

\section{Clinical uses in ophthalmology}

Amniotic membrane transplantation (AMT) is used in various ways to treat a wide variety of ophthalmic conditions. It is composed of a single epithelium layer, a thick basement membrane, and an avascular stroma. Depending on its placement and orientation, the membrane may serve as a permanent graft, a temporary patch, or may be used as a combination of both. As a graft, the amniotic membrane is placed at the site of a corneal or conjunctival tissue defect caused by a disease process or created by previous surgery.

Table I Properties and factors of amniotic membrane

\begin{tabular}{|c|c|c|}
\hline $\begin{array}{l}\text { Amniotic membrane } \\
\text { function }\end{array}$ & Factors present in amniotic membrane & Down-regulated factors \\
\hline $\begin{array}{l}\text { Promoter } \\
\text { of epithelialization }\end{array}$ & $\begin{array}{l}\text { Epidermal growth factor (EGF), keratinocyte growth factor (KGF), } \\
\text { transforming growth factor- } \alpha \text { (TGF- } \alpha \text { ), basic fibroblast growth factor (bFGF), } \\
\text { transforming growth factor- } \beta \text { (TGF- } \beta \text { ) I, } 2,3 \text {, keratinocyte growth factor } \\
\text { receptor (KGFR), hepatocyte growth factor receptor (HGFR), trefoil factor } \\
\text { family } 3 \text { peptide (TFF-3) }\end{array}$ & \\
\hline Suppresses angiogenesis & $\begin{array}{l}\left.\text { Collagen a I XVIII (Col XVIII) }{ }^{44} \text {, thrombospondin I (TSP-I }\right)^{44} \text {, tissue } \\
\text { inhibitor of metalloprotease (TIMP)-I, TIMP-2, TIMP-3, TIMP-4, interleukin- I0 } \\
\text { (IL-I0), IL-IRA, pigment epithelium derived factor (PEDF), } \\
\text { heavy chain-hyaluronic acid (HC-HA) }\end{array}$ & $\begin{array}{l}\text { Matrix metalloproteinase } \\
2 \text { (MMP-2), MMP-9 }\end{array}$ \\
\hline $\begin{array}{l}\text { Suppression } \\
\text { of inflammation }\end{array}$ & IL-I0, IL-IRA, HC-HA & $\begin{array}{l}\text { TGF } \beta-I, \text { TGF } \beta-2, \text { TGF- } \beta 3 \text {, } \\
\text { IL-6, TNF- } \alpha, \text { IL-I } \alpha, \text { IL-I } \beta \text {, IL-8 }\end{array}$ \\
\hline Suppression of scarring & & $\begin{array}{l}\text { TGF } \beta \text {-I TGF- } \beta 2, \text { TGF- } \beta 3 \text {, } \\
\text { TGF- } \beta \text { receptor II }\end{array}$ \\
\hline Antimicrobial & $\begin{array}{l}\text { Human } \beta \text {-defensins } I-4 \text {, elafin, secretory leukocyte proteinase inhibitor } \\
(\mathrm{SLPI}) \text {, cystatin } \mathrm{E}^{45}\end{array}$ & \\
\hline
\end{tabular}


The graft is placed epithelial side up and provides a basement membrane and stroma onto which normal epithelium can grow. It helps to reduce inflammation and scarring and will ultimately become integrated into the host tissue. As a patch, the amniotic membrane is placed with the epithelial side facing down. The patch covers an epithelial defect and suppresses acute inflammation in order to promote healing of the tissue underneath. The membrane is then removed, resorbed, or falls off. Occasionally, the methods are combined, and a patch is placed in order to cover and protect an underlying graft. The amniotic membrane integrates itself into the host cornea in different patterns depending on the particular ocular surface disorder or surgical technique used, as described by Resch et al. ${ }^{18}$

Amniotic membrane may be secured to the cornea or conjunctiva with sutures or with tissue adhesive such as fibrin glue. Prokera is a cryopreserved amniotic membrane that is secured to a dual polycarbonate ring and is placed in the eye similar to a contact lens, eliminating the need for sutures or glue. A recent study evaluating the indications and outcomes of Prokera in the management of ocular surface disorders concluded that it is easy to use and well tolerated, with moderate success in corneal ulcers and encouraging results in acute moderate chemical injury. The authors found recurrences of the primary condition in cases where it was used in dry eye and neurotrophic keratitis. ${ }^{19}$

In recent years, freeze-dried amniotic membrane has become an alternative to cryopreserved amniotic membrane, offering the advantage of easier surgical handling and eliminating the need for temperature-controlled transportation. Ambio2 ${ }^{\text {TM }}$ (IOP Ophthalmics), Ambio $5^{\circledR}$ (IOP Ophthalmics), and AmbioDisk are available in different sizes, are placed on the surgical site while dry, and are activated with sterile saline. Long-term storage of the cryopreserved amniotic membrane in the cell culture media with $50 \%$ glycerol was found to have no significant effect on sterility, histology, or biological properties of the membrane. ${ }^{20}$ Additionally, a recent study on augmented dried versus cryopreserved amniotic membrane found that freeze-dried amniotic membrane pretreated with lyoprotectants is more effective than conventional intact cryopreserved amniotic membrane. ${ }^{21}$

\section{Limbal stem cell deficiency (LSCD)}

Amniotic membrane is frequently used to treat conditions of partial or total LSCD. ${ }^{22}$ LSCD may be congenitally acquired but is more commonly seen after chemical and thermal burns, as well as inflammatory conditions such as Stevens Johnson syndrome (SJS), and ocular cicatricial pemphigoid.
The limbal stem cells reside at the corneoscleral limbus, and their disruption leads to visual impairment by conjunctivalization and vascularization with subsequent loss of corneal transparency. Patients with LSCD may complain of loss of vision, tearing, photophobia, and recurring episodes of pain. The treatment of LSCD depends on whether the condition is partial, total, unilateral, or bilateral. Corneal transplants often fail, and the condition is most often managed with ocular surface reconstruction with or without limbal stem cell transplantation.

Partial LSCD may not require a stem cell transplant, and has been treated successfully by simple debridement with or without AMT. Tseng et $\mathrm{a}^{22}$ used AMT to treat 42 patients with partial and total LSCD and concluded that patients with partial LSCD could be treated with AMT alone, but those with total LSCD needed AMT in combination with limbal stem cell transplantation. Konomi et $\mathrm{al}^{23}$ recently reported on amniotic membrane patch or amniotic membrane graft with patch, placed after excising abnormal conjunctival tissue for LCSD and concluded that while this method may provide temporary improvement, it does not maintain long-term stability of the ocular surface. ${ }^{23}$

Ocular surface reconstruction in combination with stem cell transplantation is required to successfully treat total stem cell deficiency. If the damage is unilateral, donor stem cells may be obtained from the unaffected eye (conjunctival limbal autograft). In this case, there is no need for systemic immunosuppression, as there is no risk of graft rejection. A study has shown successful outcomes in greater than $80 \%$ of these cases, with regression of vascularization and restoration of corneal clarity. ${ }^{24}$ Sangwan et $\mathrm{al}^{25}$ introduced a simple technique for the treatment of LSCD, in which a donor limbal graft from the unaffected eye is cut into small pieces and then expanded in the recipient eye with the help of amniotic membrane and fibrin glue. Amescua et $\mathrm{al}^{26}$ modified this technique by using a double amniotic membrane graft to protect the stem cell graft. Both techniques report a $100 \%$ graft success rate, restoration of corneal epithelium, and an improvement in visual acuity. ${ }^{25,26}$ The use of amniotic membrane to aid in vivo expansion requires a small tissue size and avoids the need for systemic immunosuppression, as required in keratolimbal allografts, with success rates comparable to conventional techniques.

If the total stem cell deficiency is bilateral, donor stem cells may be obtained from a living relative (conjunctival allograft) or cadaver (keratolimbal allograft).These techniques carry the risk of graft rejection, and patients need to be placed on systemic immunosuppression. Amniotic membrane is used to 
facilitate the growth of the limbal stem cells in vivo as well as to expand limbal stem cells ex vivo, before being transferred to the recipient eye. ${ }^{27}$ While the success rates of allografts are similar to that of conjunctival autografts in the first 1-2 years, the success rate drops due to graft failure at 5 years.

AMT has also recently shown promising results in the treatment of SJS or toxic epidermal necrolysis during the acute phase in order to prevent the cicatricial changes associated with chronic disease. The amniotic membrane is bolstered to the eyelids, as it must cover the entire ocular surface. Hsu et $\mathrm{al}^{28}$ presented a retrospective case-control study of 17 patients ( 33 eyes) treated with medical management versus 13 patients ( 25 eyes) treated with early amniotic membrane. The authors concluded that early AMT prevents severe vision loss in SJS/toxic epidermal necrolysis patients with initial moderate-to-severe ocular surface inflammation. ${ }^{28}$

\section{Corneal epithelial defects and ulcers}

Persistent epithelial defects (PEDs) are corneal wounds in which the corneal epithelium fails to regenerate in a normal time period. They may occur in situations of poor wound healing from neurotrophic or exposure keratopathy, dry eye, or inflammation. PEDs are conventionally treated with punctual occlusion and frequent lubrication with artificial or autologous tears (serum spun down from patient with a corneal defect). The use of amniotic membrane for PEDs was first reported by Lee et al in 1997. ${ }^{16}$ After epithelial debridement, an amniotic membrane patch may be sutured or glued, or a sutureless graft may be placed. If the defect involves several layers of the stroma, the membrane may be placed as a graft. Healing can be further promoted by placing a temporary tarsorrhaphy. AMT has shown an average success rate of 79\% (range, $67 \%-91 \%$ ), with rapid and complete healing of the PED within 1-4 weeks. ${ }^{29}$ Hick et $\mathrm{al}^{30}$ reported on their experience using AMT in 33 eyes of 32 patients with non-healing ulcers from a variety of causes including neurotrophic, autoimmune, and infectious etiologies. Fourteen of the ulcers were perforated, and these were managed by applying fibrin glue to the perforation site followed by AMT. Thirty of 33 eyes $(90 \%)$ epithelialized within $3.6 \pm 1.6$ weeks and had a stable corneal surface at least for 2 months after the surgery. ${ }^{30}$

AMT in combination with debridement has also been shown to be an effective surgical modality for severe shield ulcers associated with vernal keratoconjunctivitis. A recent study evaluating the clinical outcomes and complications of shield ulcers by various treatment methods concluded that Grade 1 shield ulcers responded well to medical therapy alone, Grade 2 ulcers occasionally required additional debridement or AMT, while Grade 3 ulcers required debridement and AMT for rapid re-epithelialization. ${ }^{31}$

Amniotic membrane for the treatment of Mooren's ulcer has shown conflicting results, likely due to varying ulcer severity. A retrospective study of 18 eyes reported a stabilization of the visual acuity and rapid healing of the epithelial defect after single AMT in most cases. ${ }^{32} \mathrm{~A}$ recent study of eleven eyes found that AMT was not effective in curing severe forms of Mooren's ulcer. ${ }^{33}$

\section{Bullous keratopathy}

While corneal transplantation is the first line treatment for pseudophakic bullous keratopathy (PBK) in patients with good visual potential, AMT is a less invasive option to relieve pain in those patients whose visual prognosis remains poor.

Piris et $\mathrm{al}^{34}$ first described the technique in which bullous epithelium was debrided and an amniotic membrane was sutured to the stroma and covered by a bandage contact lens. Ninety percent of the 50 patients who had intolerable pain preoperatively were pain-free 33.8 weeks after the AMT. ${ }^{34}$ AMT has been shown to be comparable in efficacy to both anterior stromal micropuncture ${ }^{35}$ and phototherapeutic keratectomy ${ }^{36}$ for the management of symptomatic PBK, and the authors suggest that combining AMT with either anterior stromal micropuncture or phototherapeutic keratectomy may improve efficacy. ${ }^{37,38}$

\section{Pterygium and conjunctival reconstruction}

Pterygium is a common benign growth of the conjunctiva that is thought to be the result of ultraviolet light exposure. . $^{39,40}$ While initially asymptomatic, the growths can be associated with dry-eye symptoms, as they cause irregular wetting of the ocular surface. Further growths can cause an unpleasing cosmetic appearance, as well as visual changes due to induced astigmatism or their approach onto the visual axis. There are several surgical techniques used in the treatment of pterygia, with the overall goal to remove and prevent recurrence. Pterygium excision with conjunctival autograft is associated with recurrence rates as low as $2 \%$, but it is more challenging, time consuming, and may also pose a problem for those patients needing future glaucoma surgery. Amniotic membrane is often used as an alternative to prevent pterygium recurrence. After the pterygium is removed, the amniotic membrane graft is sutured or glued to the bare sclera. A recent study comparing the efficacy of conjunctival autograft to AMT for the treatment of pterygium found that $7.4 \%$ of the conjunctival autograft group versus $19.2 \%$ of the amniotic membrane group 
recurred..$^{39}$ Sekeroglu et al ${ }^{40}$ reported a technique combining AMT with a narrow strip conjunctival autograft for the treatment of pterygium where $93.3 \%$ of 30 eyes had no recurrence after 1 year of follow-up. We have attached a short video demonstrating this technique (Video S1).

Amniotic membrane has been used for various other conjunctival defects and abnormalities. Palamar et $\mathrm{al}^{41}$ recently reported on their experience using amniotic membrane for ocular surface reconstruction following the excision of ocular surface squamous neoplasia and found it to be effective for large conjunctival defects. Yang et $\mathrm{al}^{42}$ recently reported that patients with severe chronic atopic keratoconjunctivitis could benefit from surgical management using amniotic membrane. Amniotic membrane has also been used to prevent scarring in trabeculectomy. A recent study by Khairy et $\mathrm{a}^{43}$ found that AMT with trabeculectomy had an intraocular pressure-lowering effect comparable to that achieved with the use of mitomycin $\mathrm{C}$, with a reduced rate of postoperative complications.

\section{Conclusion}

Amniotic membrane is being used extensively in ophthalmology, with a recent increase in its indications and techniques. It is used acutely for the management of ocular inflammatory conditions such as SJS, and it is also used to treat chronic changes of the eye such as in PBK. The ability of amniotic membrane to expand stem cells, both in vivo and ex vivo, has prompted major advancements in the treatment of LSCD. While it is most commonly used as a surgical modality for various conditions, the development of sutureless grafts has allowed for amniotic membrane placement in the office setting avoiding the time, expense, and complications that may be associated with a surgical procedure. New uses for amniotic membrane are on the horizon as its structure and mechanism of action become even better understood, and as new methods of preservation and delivery are introduced.

\section{Acknowledgment}

This study was supported in part from an RPB grant.

\section{Disclosure}

The authors report no conflicts of interest in this work.

\section{References}

1. Davis JW. Skin transplantation with a review of 550 cases at the Johns Hopkins Hospital. Johns Hopkins Med J. 1910;15:307-396.

2. Sabella N. Use of fetal membranes in kin grafting. Med Rec NY. 1913;83:478-480.

3. Stern M. The grafting of preserved amniotic membrane to burned and ulcerated surfaces, substituting skin grafts: a preliminary report. JAMA. 1913;60(13):973-974.
4. Khademi B, Bahranifard H, Azarpira N, Behboodi E. Clinical application of amniotic membrane as a biologic dressing in oral cavity and pharyngeal defects after tumor resection. Arch Iran Med. 2013;16(9):503-506.

5. Zohar Y, Talmi YP, Finkelstein Y, Shvili Y, Sadov R, Laurian N. Use of human amniotic membrane in otolaryngologic practice. Laryngoscope. 1987;97(8 Pt 1):978-980.

6. Hasegawa M, Fujisawa H, Hayashi Y, Yamashita J. Autologous amnion graft for repair of myelomeningocele: technical note and clinical implication. J Clin Neurosci. 2004;11(4):408-411.

7. Burger K. Artificial vagina reconstruction with the help of amnion. Zentralb Gynaecol. 1937;61:2437-2440.

8. Davis GE, Blaker SN, Engvall E, Varon S, Manthorpe M, Gage FH. Human amnion membrane serves as a substratum for growing axons in vitro and in vivo. Science. 1987;236(4805):1106-1109.

9. Rennekampff HO, Dohrmann P, Föry R, Fändrich F. Evaluation of amniotic membrane as adhesion prophylaxis in a novel surgical gastroschisis model. J Invest Surg. 1994;(3):187-193.

10. Muralidharan S, Gu J, Laub GW, Cichon R, Daloisio C, McGrath LB. A new biological membrane for pericardial closure. $J$ Biomed Mater Res. 1991;(10):1201-1209.

11. De Rötth A. Plastic repair of conjunctival defects with fetal membranes. Arch Ophthalmol. 1940;23(3):522-525.

12. Sorsby A, Haythorne J, Reed H. Further experience with amniotic membrane grafts in caustic burns of the eye. Br J Ophthalmol. 1947; 31(7):409-418.

13. Collin JR. Peritoneal autografts in conjunctival replacement. $\mathrm{Br} J$ Ophthalmol. 1975;59(5):288-293.

14. Dua HS, Gomes JA, King AJ, Maharajan VS. The amniotic membrane in ophthalmology. Surv Ophthalmol. 2004;49(1):51-77.

15. Tseng SC, Prabhasawat P, Lee SH. Amniotic membrane transplantation for conjunctival surface reconstruction. Am J Ophthalmol. 1997;124(6):765-774.

16. Lee SH, Tseng SC. Amniotic membrane transplantation for persistent epithelial defects with ulceration. Am J Ophthalmol. 1997;123(3):303-312.

17. Dua HS. Amniotic membrane transplantation. Br J Ophthalmol. 1999;83(6):748-752.

18. Resch MD, Schlötzer-Schrehardt U, Hofmann-Rummelt C, et al. Integration patterns of cryopreserved amniotic membranes into the human cornea. Ophthalmology. 2006;113(11):1927-1935.

19. Suri K, Kosker M, Raber IM, et al. Sutureless amniotic membrane ProKera for ocular surface disorders: short-term results. Eye Contact Lens. 2013;39(5):341-347.

20. Thomasen H, Pauklin M, Noelle B, et al. The effect of long-term storage on the biological and histological properties of cryopreserved amniotic membrane. Curr Eye Res. 2011;36(3):247-255.

21. Allen Cl, Clare G, Stewart EA, et al. Augmented dried versus cryopreserved amniotic membrane as an ocular surface dressing. PLoS One. 2013;8(10):e78441.

22. Tseng SC, Prabhasawat P, Barton K, Gray T, Meller D. Amniotic membrane transplantation with or without limbal allografts for corneal surface reconstruction in patients with limbal stem cell deficiency. Arch Ophthalmol. 1998;116(4):431-441.

23. Konomi K, Satake Y, Shimmura S, Tsubota K, Shimazaki J. Long-term results of amniotic membrane transplantation for partial limbal deficiency. Cornea. 2013;32(8):1110-1115.

24. Meller D, Pires RT, Mack RJ, et al. Amniotic membrane transplantation for acute chemical or thermal burns. Ophthalmology. 2000;107(5):980-990.

25. Sangwan VS, Basu S, MacNeil S, Balasubramanian D. Simple limbal epithelial transplantation (SLET): a novel surgical technique for the treatment of unilateral limbal stem cell deficiency. Br J Ophthalmol. 2012;96(7):931-934.

26. Amescua G, Atallah M, Nikpoor N, Galor A, Perez VL. Modified simple limbal epithelial transplantation using cryopreserved amniotic membrane for unilateral limbal stem cell deficiency. Am J Ophthalmol. 2014;158(3):469-475. 
27. Shortt AJ, Secker GA, Rajan MS, et al. Ex vivo expansion and transplantation of limbal epithelial stem cells. Ophthalmology. 2008;115(11):1989-1997.

28. Hsu M, Jayaram A, Verner R, Lin A, Bouchard C. Indications and outcomes of amniotic membrane transplantation in the management of acute Stevens-Johnson syndrome and toxic epidermal necrolysis: a case-control study. Cornea. 2012;31(12):1394-1402.

29. Liu J, Sheha H, Fu Y, Liang L, Tseng SC. Update on amniotic membrane transplantation. Expert Rev Ophthalmol. 2010;5(5):645-661.

30. Hick S, Demers PE, Brunette I, La C, Mabon M, Duchesne B. Amniotic membrane transplantation and fibrin glue in the management of corneal ulcers and perforations: a review of 33 cases. Cornea. 2005;24(4):369-377.

31. Reddy JC, Basu S, Saboo US, Murthy SI, Vaddavalli PK, Sangwan VS. Management, clinical outcomes, and complications of shield ulcers in vernal keratoconjunctivitis. Am J Ophthalmol. 2013;155(3):550-559.

32. Ngan ND, Chau HT. Amniotic membrane transplantation for Mooren's ulcer. Clin Experiment Ophthalmol. 2011;13(5):386-392.

33. Schallenberg M, Westekemper H, Steuhl KP, Meller D. Amniotic membrane transplantation ineffective as additional therapy in patients with aggressive Mooren's ulcer. BMC Ophthalmol. 2013;13:81.

34. Pires RT, Tseng SC, Prabhasawat P, et al. Amniotic membrane transplantation for symptomatic bullous keratopathy. Arch Ophthalmol. 1999;117(10):1291-1297.

35. Paris Fdos S, Gonçalves ED, Campos MS, Sato EH, Dua HS, Gomes JÁ. Amniotic membrane transplantation versus anterior stromal puncture in bullous keratopathy: a comparative study. $\mathrm{Br} J$ Ophthalmol. 2013;97(8):980-984.

36. Chawla B, Sharma N, Tandon R, Kalaivani M, Titiyal JS, Vajpayee RB. Comparative evaluation of phototherapeutic keratectomy and amniotic membrane transplantation for management of symptomatic chronic bullous keratopathy. Cornea. 2010;29(9):976-979.
37. Sonmez B, Kim BT, Aldave AJ. Amniotic membrane transplantation with anterior stromal micropuncture for treatment of painful bullous keratopathy in eyes with poor visual potential. Cornea. 2007;26(2):227-229.

38. Vyas S, Rathi V. Combined phototherapeutic keratectomy and amniotic membrane grafts for symptomatic bullous keratopathy. Cornea. 2009;28(9):1028-1031.

39. Liang W, Li R, Deng X. Comparison of the efficacy of pterygium resection combined with conjunctival autograft versus pterygium resection combined with amniotic membrane transplantation. Eye Sci. 2012;27(2):102-105.

40. Taylan Sekeroglu H, Erdem E, Dogan NC, Yagmur M, Ersoz R, Dogan A. Sutureless amniotic membrane transplantation combined with narrow-strip conjunctival autograft for pterygium. Int Ophthalmol. 2011;31(6):433-438.

41. Palamar M, Kaya E, Egrilmez S, Akalin T, Yagci A. Amniotic membrane transplantation in surgical management of ocular surface squamous neoplasias: long-term results. Eye (Lond). Epub July 4, 2014.

42. Yang J, Yang FH, Peng CH, Erol D, Tsang SH, Li XR. Surgical treatment of 32 cases of long-term atopic keratoconjunctivitis using the amniotic membrane. Eye (Lond). 2013;27(11):1254-1262.

43. Khairy HA, Elsawy MF. Trabeculectomy with mitomycin-C versus trabeculectomy with amniotic membrane transplant: a medium-term randomized, controlled trial. J Glaucoma. Epub May 19, 2014.

44. Hao Y. Identification of antiangiogenic and antiinflammatory proteins in human amniotic membrane. Cornea. 2000;19(3):348-352.

45. Ni J, Abrahamson M, Fernandez MA et al. Cystatin E is a Novel Human Cysteine Proteinase Inhibitor with Structural Resemblence to Family 2 Cystatins. J Biol Chem. 1997;272(16):10853-10858.
Chronic Wound Care Management and Research

\section{Publish your work in this journal}

Chronic Wound Care Management and Research is an international, peer reviewed, open access, online journal publishing original research, reviews, editorials, and commentaries on the causes and management of chronic wounds and the major issues related to chronic wound management. Topics also include chronic wounds as comorbidities to other

\section{Dovepress}

conditions, patient adherence to therapy, and the economic burden of chronic wounds. The manuscript management system is completely online and includes a very quick and fair peer review system, which is all easy to use. Visit http://www.dovepress.com/testimonials.php to read real quotes from published authors. 